Abstracta Iranica Abstracta Iranica

Revue bibliographique pour le domaine irano-aryen

Volume 24 | 2003

Comptes rendus des publications de 2001

\title{
Bulletin d'histoire achéménide II. BHAch II, 1997-2000 (Persika 2). Paris, Thotm éditions, 2001, 334 p.
}

\section{Rémy Boucharlat}

\section{Q OpenEdition}

1 Journals

Édition électronique

URL : http://journals.openedition.org/abstractairanica/34280

ISSN : 1961-960X

\section{Éditeur :}

CNRS (UMR 7528 Mondes iraniens et indiens), Éditions de l'IFRI

\section{Édition imprimée}

Date de publication : 15 mai 2003

ISSN : 0240-8910

\section{Référence électronique}

Rémy Boucharlat, «Bulletin d'histoire achéménide II. BHAch II, 1997-2000 (Persika 2). Paris, Thotm éditions, 2001, 334 p. », Abstracta Iranica [En ligne], Volume 24 | 2003, document 53, mis en ligne le 05 janvier 2010, consulté le 25 septembre 2020. URL : http://journals.openedition.org/abstractairanica/ 34280

Ce document a été généré automatiquement le 25 septembre 2020.

Tous droits réservés 
Bulletin d'histoire achéménide II. BHAch II, 1997-2000 (Persika 2). Paris, Thotm éditions, 2001, 334 p.

Rémy Boucharlat 
1 Malgré l'ampleur de la tâche, P.B. persiste et donne une suite à son BHAch I publié en 1997, (Abs. Ir. 20-21, n 8) qui actualisait déjà la bibliographie de son Histoire de l'empire perse (1996). Ce premier volume est disponible sur internet :

3 Rappelons que cette série n'est pas seulement un bulletin critique ou une compilation, mais bien un regard d'historien, au sens le plus large du terme, qui embrasse l'ensemble de la production scientifique concernant les études sur le monde perseachéménide dans toute l'étendue de son territoire et de son impact. L'inventaire structuré que donne l'A. permet de connaître tout ce qui est nouveau - entendu comme tel, et non pas seulement récent: les nouvelles données, apportées surtout par les recherches archéologiques, mais aussi les articles et les livres qui fournissent des idées nouvelles ou renouvelées sur une vieille question ou un fait que l'on croit bien connu ou compris (voir ses remarques à ce sujet dans « New Trends in Achaemenid History ", disponible sur :

4 http://www.fisiran.org/achaemenid.htm).

5 C'est une œuvre personnelle de chercheur, mais parce que tout y est mentionné et en général commenté, le lecteur le plus exigeant l'utilisera aussi comme un outil indispensable, d'autant plus que celui-ci contient trois index (noms propres, thèmes et auteurs). L'illustration est peu abondante mais judicieusement choisie; ce sont en général des documents nouveaux qui ne sont pas tous facilement accessibles en dehors du cercle des spécialistes de chaque domaine ou région.

6 Les publications mentionnées s'arrêtent à septembre 2000 ; il faut maintenant attendre le BHAch III, en cours de constitution.

\section{INDEX}

Thèmes : 3.2.2. Pré-Achéménides et Achéménides

\section{AUTEURS}

RÉMY BOUCHARLAT

CNRS - Lyon 